\title{
Dr. Arvid Lindau and discovery of von Hippel-Lindau disease
}

\author{
Kristin Huntoon, PhD, DO,,2 Edward H. Oldfield, MD, ${ }^{1,3}$ and Russell R. Lonser, MD ${ }^{1,2}$ \\ 'Department of Neurological Surgery, The Ohio State University Wexner Medical Center, Columbus, Ohio; ${ }^{2}$ Surgical Neurology \\ Branch, National Institute of Neurological Disorders and Stroke, National Institutes of Health, Bethesda, Maryland; and \\ ${ }^{3}$ Department of Neurological Surgery, University of Virginia Health Sciences Center, Charlottesville, Virginia
}

\begin{abstract}
Arvid Lindau, MD, PhD, consolidated the disparate array of benign and malignant visceral and nervous system lesions into the neoplastic syndrome known as von Hippel-Lindau (VHL) disease. Based on this pioneering work, Dr. Lindau was awarded both a Rockefeller fellowship to work in Dr. Harvey Cushing's laboratory in Boston, Massachusetts, and the Lennmalm Prize. While working in Dr. Cushing's laboratory, Dr. Lindau continued his study of CNS hemangioblastomas. His work with Dr. Cushing led to their lifelong friendship and scientific collaboration. In this paper the authors describe Arvid Lindau's pioneering work in nervous system tumor pathology, his relationship to Dr. Cushing, and his role in advancing neurological surgery and research in Europe.
\end{abstract}

http://thejns.org/doi/abs/10.3171/2015.1.JNS131963

KEY WORDS von Hippel-Lindau disease; Arvid Lindau; Harvey Cushing; hemangioblastoma; history

A RVID Lindau, MD, $\mathrm{PhD}$, is best known for the eponymous syndrome he described in the early 20th century, von Hippel-Lindau (VHL) disease. While he was a pathologist, Dr. Lindau made significant contributions to neurosurgical research and the development of the specialty in Europe. After publishing his doctoral thesis on VHL disease, Dr. Lindau was awarded a Rockefeller fellowship to study in the laboratory of Harvey Cushing. This initiated a lifelong collegial relationship between the two physicians that was based on mutual admiration and scientific exchange. In this paper we describe Arvid Lindau's pioneering work in CNS tumor pathology, his role in the development of neurological surgery and related research in Europe, as well as his relationship with Dr. Cushing.

\section{Early Years}

Arvid Vilhelm Lindau was born in Malmö, Sweden, on July 23, 1892. He was the son of Anders Lindau, MD, a regimental surgeon, and Ellen Edlund. During his undergraduate training at the University of Lund (1910 to 1914), he studied medicine (BA), while simultaneously completing his reserve military officer examination. He went on to complete medical school and a doctorate of philosophy at the University of Lund (MD, 1923; PhD, 1926). Upon completion of his graduate degrees, he specialized in pathology and bacteriology at the University of Lund and the Karolinska Institute. ${ }^{17} \mathrm{He}$ would go on to train as a military officer and serve as a physician in the army. He was also the prosector in the Department of Pathology in the General Hospital in Malmö, Sweden.

During his studies at the University of Lund and while working as a pathologist, Dr. Lindau observed 2 cerebellar cysts with small knob-shaped hemangioblastomas in the cyst wall. Curious, he discovered similar cerebellar cysts associated with hemangioblastomas in museum preparations in Sweden (Lund, Uppsala, Stockholm, and Goteborg), as well as other cases in the medical literature., ${ }^{9,10,19}$ Additionally, in postmortem studies of patients with cerebellar hemangioblastomas that Dr. Lindau performed, he found cysts in the pancreas, liver, and kidneys. He also found pheochromocytomas, angiomas (now known as hemangioblastomas) of the liver and spinal cord, and retinal angiomas (now known as retinal hemangioblastomas). Specifically, he was intrigued by the co-occurrence of these visceral and nervous system lesions in cases with retinal vascular changes (angiomatosis retinae). 
In 1925, he was awarded a travel grant from the pathology faculty at the University of Lund to pursue his hypothesis that these findings, when they coexist in an individual, represent a single disease process. To accomplish his study, Dr. Lindau undertook an extensive journey throughout Europe examining the pathological and anatomical specimens of reported angiomatosis retinae. He visited Dr. J. Tannenberg (Frankfurt, Germany); Dr. P. Ernest, Dr. A. Wagenmann, and Dr. E. Seidel (Heidelberg, Germany); Dr. W. Berblinger and Dr. R. Brandt (Jena, Sweden); Dr. Reinhardt (Leipzig, Germany); Dr. E. von Hippel (Göttingen, Germany); Dr. Elschnig, Dr. Gohn, and Dr. K. Terplan (Prague, Czech Republic); Dr. O. Lubarsch (Berlin, Germany); as well as faculty in Stockholm, Umeå, Göteberg, Uppsala, and Malmö, Sweden; and Copenhagen, Denmark.

Upon returning to Sweden, Dr. Lindau finished his dissertation, "Studien über Kleinhirncysten. Bau, Pathogenese und Beziehungen zur Angiomatosae retinae" ("Studies on Cerebellar Cysts, Construction, Pathogenesis and Relationship to Angiomatosis retinae"). ${ }^{15}$ Suitably detailed and long enough to warrant its own issue, the thesis was published in Acta Pathologica and Microbiologica Scandinavica as a supplement (126 pages in total). The thesis begins with a historical review of cerebellar cysts, in addition to containing 71 illustrations (drawings and related photographs; Fig. 1). While the title of Dr. Lindau's thesis references cerebellar cyst development, pathology, and their association with angiomatosis retinae, the thesis also describes the features of other cerebellar cysts (not related to angiomatosis retinae), including other tumor-related cysts, parasitic cysts, as well as hemorrhage- or infarctionrelated pseudocysts.

\section{Formation of the Thesis}

Dr. Lindau's first insights into the syndrome that would become known as VHL disease began when he performed an autopsy in Stockholm (Case 4 of his thesis), in which he described an angiomatous cyst of the cerebellum along with bilateral adenomas of the adrenals. What he found even more interesting was that this patient had previously had an "arteriovenous aneurysm" of the right retina for which an enucleation had been performed 8 years before the patient's death. The retinal specimen had been preserved without histological examination. When Lindau examined it, he observed a small capillary hemangiomanow known as a hemangioblastoma in modern pathological nomenclature-in the peripheral retina.

In 1928, Drs. Cushing and Bailey introduced the term "hemangioblastoma" into the literature. Moreover, they divided nervous system vascular malformations into 2 categories, including hemangioblastomas and angiomatous malformations. ${ }^{6}$ Later, in 1931, Dr. Lindau described hemangioblastomas based on distinct criteria, including "unmistakable neoplasticity" with "composition of blood vessel elements" and a "tendency toward cyst formation." Dr. Lindau proposed that the hemangioblastomatous tissue may derive from a "congenital anlage" and hypothesized that the neoplastic cells are histologically similar to an "...embryological type of the tumor cells."13 More- over, Dr. Lindau cited Roussy and Oberling,,$^{20}$ who “...have found evidence of hematopoiesis, a circumstance that Drs. Cushing and Bailey, as well as myself [Arvid Lindau], have sought for in vain." Dr. Lindau's hypothesis would be confirmed by modern molecular biological techniques that demonstrate that the neoplastic cell of origin in hemangioblastomas is derived from embryologically arrested hemangioblasts capable of blood and endothelial cell formation. ${ }^{16,18}$

Dr. Lindau began studying angiomatosis retinae, a rare malady with familial tendency of which some 50 cases had been reported previously, which he believed were related to the cerebellar cysts he had observed in cadavers. While reviewing these cases, he found that approximately $20 \%$ of the patients had also been known to have intracranial complications. Similarly, other clinician-scientists at the time, including Czermak (1905), described 2 cases of angiomatosis retinae in which the patients on postmortem examination were found to have coexisting cerebellar cysts. The cerebellar cysts in these cases were believed to be the cause of death.? Moreover, Dr. Lindau found other reports of patients with brain tumors that had associated angiomatosis retinae. ${ }^{2,3}$

Although others, including Czermak, Jacoby, von Dzialowski, and Brandt had observed the combination of retinal and cerebellar lesions, no one had defined the association until Dr. Lindau. In total, he collected data on 40 cases of cerebellar cysts, 24 from the literature and 16 of his own. Of the latter 16 personal cases, 8 patients had pancreatic cysts, 6 had renal cell carcinomas (hydronephromas), 10 had renal cysts, and 2 had angiomatosis retinae. He described other visceral lesions in his patients, including an adrenal adenoma and an epididymal tumor. ${ }^{14} \mathrm{He}-$ mangioblastomas were not confined to the cerebellum, but also appeared in the medullary region of the brainstem, as well as the spinal cord. Lastly, he compared microscopic tissue sections from retinal and rhomboencephalic-cord lesions in his collection against other reported cases. ${ }^{3,7,8,11}$ The similarity of these lesions confirmed to Dr. Lindau that they were the product of one underlying syndrome.

Dr. Lindau found that small, highly vascular mural tumors could be associated with cerebellar cysts. He emphasized that meticulous inspection of the cyst wall was critical or mural hemangioblastoma could be missed (a feature described in the microsurgical era).${ }^{10} \mathrm{He}$ described their location as frequently near or on the cerebellar surface and characterized by marked hypertrophy of afferent and efferent vessels. Microscopically, he described hemangioblastomas as complex lesions composed of vascular elements containing no nerve or glial cells. He also noted that they differed from capillary angiomas by the abundant reticulin between capillaries and the lipid-filled interstitial cells throughout the tumor mass.

In his hypothesis of the origins of VHL disease, Dr. Lindau suggested that VHL-associated maldevelopment may occur during the third month of fetal life. He based this suggestion on the fact that for a relatively long period of development, the retina is completely avascular; only in the third embryonic month comes the formation of retina receptacles that develop from the central retinal artery. At the same time, there is a proliferation of "nervous 


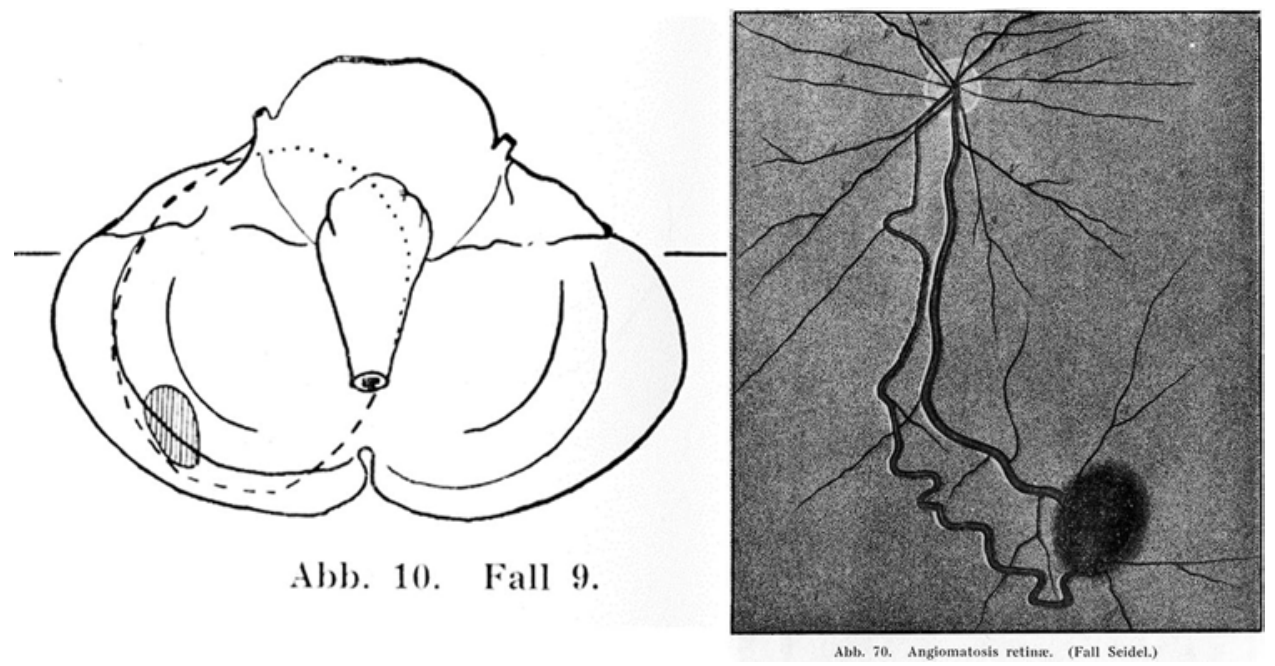

FIG. 1. Drawings by Arvid Lindau from his thesis, "Studien über Kleinhirncysten. Bau, Pathogenese und Beziehungen zur Angiomatosae retinae" ("Studies on Cerebellar Cysts, Construction, Pathogenesis and Relationship to Angiomatosis retinae") in Acta Pathologica and Microbiologica Scandinavica.14 Left: A drawing of a cystic cerebellar lesion in a patient affected by VHL disease. dashed line = cyst; gray area = hemangioblastoma. Right: A drawing of "angiomatosis retinae" (now known as a retinal hemangioblastoma) based on a specimen from a patient affected by VHL disease.

elements" consisting of the coordination of mesenchymal development and angiogenesis, as described in Antoni's other studies from that time period. ${ }^{1}$ Furthermore, he correlated the location of hemangioblastomas of the cerebellum with distinct developmental changes, including vascular planes, delayed or sequestered mesenchyme in the velum of the cerebellum, and distinct directional growth changes occurring in the cerebellum at 3 months.

\section{Relationship With Dr. Cushing}

Drs. Cushing and Lindau's long relationship of mentorship and mutual respect began when Dr. Cushing was preparing a manuscript on cerebellar hemangioblastomas and came across Dr. Lindau's thesis. Dr. Cushing was impressed by the depth of Dr. Lindau's study and intuition in describing this syndrome. He praised Dr. Lindau in his publication "Hemangiomas of cerebellum and retina (Lindau's disease): with the report of a case," which was the first time the neoplasia syndrome was identified with Dr. Lindau's name..$^{5}$ It was Drs. Cushing and Bailey who made Dr. Lindau's work on VHL disease known in the US. Percival Bailey said to Dr. Lindau, "You have been the first to bring the different elements together and show definitely that they have an essential relationship. Both Dr. Cushing and I feel that you entirely deserve the principal credit." Dr. Cushing wrote to Dr. Lindau, "I am sure your important discovery will make its own way in time. There is an old adage that no man is appreciated in his own country" (Fig. 2).

Dr. Lindau was awarded the Rockefeller fellowship after he and Dr. Cushing had exchanged letters. Dr. Cushing went to great lengths to ensure Dr. Lindau's time in Boston was "profitable" by helping him network with the scientific and medical heavyweights of their time, as well as arranging dinners and lectures for Dr. Lindau. It is clear that, as Dr. Cushing served as a mentor to Dr. Lindau, Dr. Lindau also understood himself to be a student of Dr.
Cushing (Fig. 3). On returning to Sweden in January 1932, Dr. Lindau wrote to Dr. Cushing, "I will always regard myself as a distant pupil of yours." 12 Over time, as Dr. Lindau became an established leader in the medical community of Lund, his interactions with Dr. Cushing became more of a relationship of colleagues and less of a mentor/ pupil relationship. Dr. Cushing visited Dr. Lindau's lab-

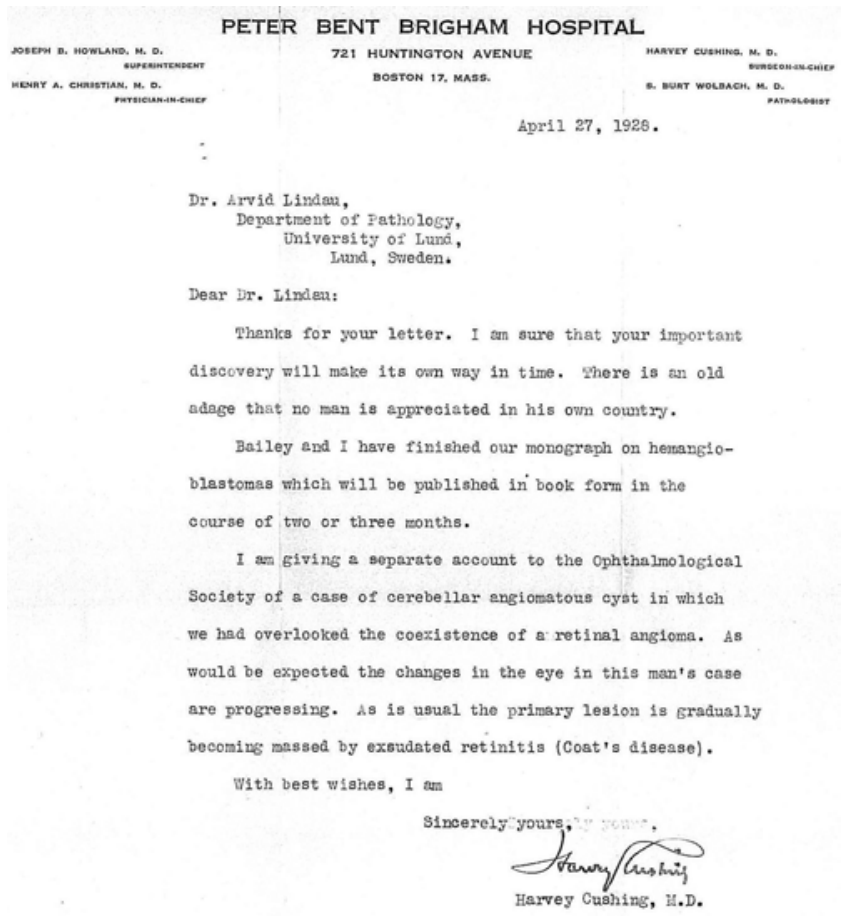

FIG. 2. Letter from Harvey Cushing to Arvid Lindau dated April 27, 1928. The letter was sent by Harvey Cushing while he was preparing his manuscript, "Hemangioblastoma of cerebellum and retina (Lindau's disease): with the report of a case." Courtesy of the Lund University Library Archives. 


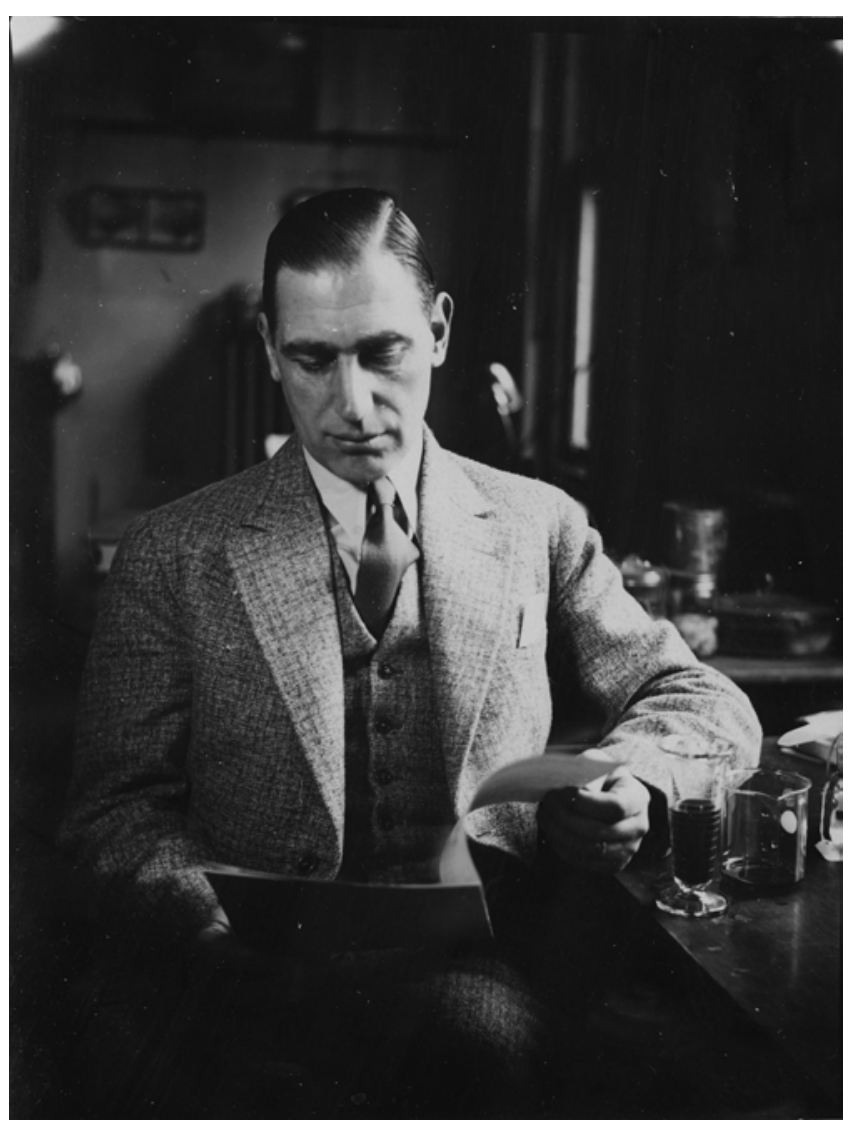

FIG. 3. Photograph of Arvid Lindau (courtesy of the Yale University, Harvey Cushing/John Hay Whitney Medical Library). The date and location are unknown but are believed to be during the time period in which Arvid Lindau was a Rockefeller fellow under the mentorship of Harvey Cushing in Boston, Massachusetts.

oratory in 1934, while attending the Royal Academy of Sciences in Sweden. Dr. Cushing was fascinated with the vascular tumors of the nervous system that Dr. Lindau had collected.

Drs. Cushing and Lindau's collaboration and friendship was not limited to the study of hemangioblastomas. Between 1932 and Dr. Cushing's death in 1939, they exchanged ideas and theories, manuscripts, theses, books, photographs, artwork, and pathology specimens with each other. The breadth of their discussions, their collegiality, and their respect for the other's hypotheses (even when they were in disagreement) was remarkable. One such example is over Dr. Cushing's report "Peptic ulcer and the interbrain." ${ }^{4}$ Dr. Lindau wrote in a letter dated August 29, 1932:

With great interest I read your article on peptic ulcer and the interbrain. It is surely most important that attention be drawn to this very neglected field and the survey covers the gap very thoroughly. But my private opinion is that these acute ulcers might be closer related to Beneter's erosions than to real chronic ulcers in human beings... But this is of course only trifles and the scope of the article is not to tell all about ulcers.

In other letters, Dr. Lindau speaks of his relationship with European neurosurgeons, efforts to have Dr. Cush- ing awarded the Nobel Prize, and hopes that their paths may cross again. Dr. Lindau writes in one such letter dated February 22, 1935:

It is possible the English neurosurgical club is going to have this year's meeting with Olivecrona in Stockholm. I will join them there and Cairns has promised to stay with me in Lund. I like Cairns very much and he has been very kind to several of my friends who have visited London. Several of your friends are working for you as to the Nobel Prize and I really hope that we will have this agreeable reason of seeing you again here in Sweden.

In 1932, Dr. Lindau visited Dr. Cushing in Boston. Dr. Lindau's son, Jan Lindau, describes an interaction that occurred on rounds between his father and Dr. Cushing. A patient who Dr. Cushing had performed surgery on and was believed to have VHL disease had stopped the team as they passed and looking at Dr. Cushing said, "Doctor, I want to thank you for saving my life." Dr. Cushing replied, "Don't thank me," pointing to Dr. Lindau, "You should thank this young man here." From Dr. Lindau's perspective, this one moment made all the hard work of his lifetime worthwhile. ${ }^{15}$

\section{VHL Nomenclature}

Because it was Dr. Lindau who linked the systemic features of the disease to retinal and craniospinal hemangioblastomas, "Lindau's disease" was initially proposed by Drs. Cushing and Bailey to describe this neoplasia syndrome. Later, based on Dr. von Hippel's original description of retinal hemangioblastomas in a patient with the disease in the ophthalmological literature, "von Hippel" was added to "Lindau's disease" to define the neoplasia syndrome as VHL in the 1930s. However, Dr. von Hippel and other physicians of the time never made the connection between retinal angiomas and other associated tumors in patients with VHL disease. Nevertheless, "VHL" was uniformly used in the literature in the 1970s to describe the syndrome in the medical literature. Even so, because of Dr. Lindau's understanding and connection of the various features of VHL disease, many clinicians believed VHL was best defined as "Lindau's disease."

\section{Career and Personal Life of Dr. Lindau}

In 1933, Dr. Lindau became Professor of Pathology, Bacteriology, and General Health Science (allmän hälsovårdslära) at the University of Lund. Later, in 1944, he became Head of the Institute of Bacteriology and Pathological Anatomy (succeeding Dr. John Forssman). He also was a Swedish military physician from 1924 to 1934 , concurrent with his academic position. As head of the Institute of Pathological Anatomy and Bacteriology, he focused on clinical bacteriology and immunology, including tuberculosis, sarcoidosis, medication-resistant bacterial infections, and Wassermann's reaction. In addition to his famous doctoral dissertation, Dr. Lindau published 40 original studies on syphilis, tuberculosis, CNS vascular tumors, and the pathogenesis of amaurotic familial idiocy in Tay-Sachs disease. He was awarded the Lennmalm Prize for his thesis work in recognizing a new syndrome (VHL) in 1929 from the Swedish Medical Society. 
It is clear that Dr. Cushing was not alone in his admiration of Dr. Lindau. By all accounts, Dr. Lindau was a devoted and fun-loving colleague, university faculty member, local governmental official, and family man. He was active in his community, refereeing local soccer matches and taking an interest in civic affairs, which included holding various official positions in the Lund city government. He also made a point of enjoying his life outside of work, enthusiastically enjoying outdoor activities, music, motorcycles, and his 1959 Studebaker coupe, the only one in Sweden. Most notably, Dr. Lindau was an avid supporter of orienteering and an advocate for the sports at the university, going so far as to establish improved facilities for the students.

Owing in part to his military training, Dr. Lindau kept a regimented daily routine. He would read at least 3 scientific articles before bicycling to the Institute of Pathology in Lund. After his daily lectures, he would help his coworkers with ongoing projects and visit with international guests, students, or colleagues. After dinner, he would be off to whatever the evening held for him, from professional gatherings to handball matches to town meetings. He would end his day the same way he began it, keeping up with the latest scholarly literature, although in the evening he would accompany his reading with a large cigar and a glass of abricot or whiskey.

In 1923, Lindau married Ida Lowegren and 10 years later they adopted their only child, Jan Lindau. While he was a dedicated family man and closely involved with raising his son, he also regretted that he was not able to be there more for his family. In 1958, near the end of his life, Dr. Lindau was scheduled for surgery and was concerned that it might not go well. He left a letter for his wife reading, "Forgive me for not always being the way I wanted. Count only the bright days." He died 2 days later from a pulmonary embolism at the age of 67.

Dr. Arvid Lindau worked collegially with his fellow physicians, at home and abroad, to advance the treatment and prevention of disease, particularly in the field of neurosurgery, and strived to freely disseminate new knowledge. While continuing to make groundbreaking discoveries, he also served his community and his country through his military service and civic involvement.

\section{Acknowledgment}

We appreciate the assistance of staffs at the National Library of Medicine, University of Lund Library, and Yale University (Harvey Cushing/John Hay Whitney Medical Library).

\section{References}

1. Antoni N: Kystes cérébelleux, la syringomyélie du cervelet. Á propos de trois cas personnels. Acta Otolaryngol 9:1-42, 1926

2. Berblinger W: Zur Auffassung von der sogenannten v. Hippeischen Krankheit der Netzhaut. Graefe's Arch Clin Ophthalmol 110:395-413, 1922
3. Brandt R: Zur frage des angiomatosis retinae. Graefe's Arch Clin Ophthalmol 106:127-165, 1921

4. Cushing H: Peptic ulcer and the interbrain. Surg Gynec Obst 55:1-34, 1932

5. Cushing H, Bailey P: Hemangiomas of cerebellum and retina (Lindau's disease): with the report of a case. Trans Am Ophthalmol Soc 26:182-202, 1928

6. Cushing H, Bailey P: Tumors Arising from Blood-Vessels of the Brain: Angiomatous Malformations and Hemangioblastomas. Springfield, IL: Charles C Thomas, 1928

7. Czermak W: Pathologisch-anatomisches Befund bei der von E. v. Hippel beschriebenen sehr seltenen Netzhauterkrankung. Ber Dtsche Ophthalmol Ges 32:184-195, 1905

8. Hammar E: Nederl. Tijdschr. v. Geneesk. LXXI²:785-789, 1927

9. Jackson H: A series of cases illustrative of cerebral pathology. I. Cerebral tumors. Med Times Hops Gaz (London) 2:541-568, 1872

10. Jagannathan J, Lonser RR, Smith R, DeVroom HL, Oldfield $\mathrm{EH}$ : Surgical management of cerebellar hemangioblastomas in patients with von Hippel-Lindau disease. J Neurosurg 108:210-222, 2008

11. Jakoby E: Klin Monatsbl f Augenh XLIII:138, 1905

12. Kanno H, Kondo K, Ito S, Yamamoto I, Fujii S, Torigoe S, et al: Somatic mutations of the von Hippel-Lindau tumor suppressor gene in sporadic central nervous system hemangioblastomas. Cancer Res 54:4845-4847, 1994

13. Lindau A: Discussion on vascular tumours of the brain and spinal cord: joint discussion no. 1. Proc R Soc Med 24:363388, 1931

14. Lindau A: Studiën über Kleinhirnsystem: Bau, Pathogenese und Beziehungen zur Angiomatosis Retinae. Acta Pathol Microbiol Scand Suppl I:1, 1926

15. Lindau J: My father, Arvid Lindau. VHL Family Forum 5:3, 1997

16. Merrill MJ, Edwards NA, Lonser RR: Hemangioblastomaassociated mast cells in von Hippel-Lindau disease are tumor derived. Blood 121:859-860, 2013

17. Neumann HP: [Arvid Lindau on his 100th birthday.] Pathologe 14:178-180, 1993 (Ger).

18. Park DM, Zhuang Z, Chen L, Szerlip N, Maric I, Li J, et al: von Hippel-Lindau disease-associated hemangioblastomas are derived from embryologic multipotent cells. PLoS Med 4:e60, 2007

19. Pye-Smith PH: Cyst of the cerebellum with numerous small cysts in the pancreas and the kidneys. Trans Pathol Soc Lond 36:17-21, 1885

20. Roussy G, Oberling C: Les tumeurs angiomateuses des centres nerveux. Presse Méd 38:179-185, 1930

\section{Author Contributions}

Conception and design: Huntoon, Lonser. Acquisition of data: Huntoon. Analysis and interpretation of data: Huntoon, Lonser. Drafting the article: all authors. Critically revising the article: all authors. Reviewed submitted version of manuscript: all authors. Approved the final version of the manuscript on behalf of all authors: Huntoon. Study supervision: Oldfield, Lonser.

\section{Correspondence}

Kristin Huntoon, Department of Neurological Surgery, The Ohio State University Wexner Medical Center, 410 W. 10th Ave., Doan Hall N1047, Columbus, OH 43210. email: kristin. huntoon@osumc.edu. 